\title{
Yaşlıların "Sokağa Çıkma Yasağı” Üzerine Görüşleri: Telefon Anketi
}

\author{
The Perspective of Older People on "COVID-19 Curfew": A Phone Survey
}

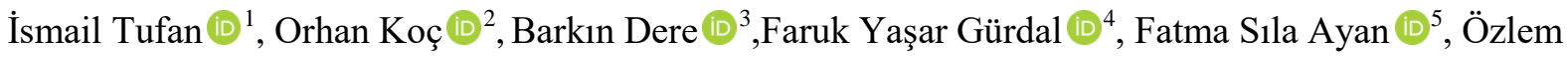 \\ Özgür (iD ${ }^{1}$, Gülüşan Özgün Başıbüyük (D) ${ }^{1}$, Hasan Hüseyin Başıbüyük (iD ${ }^{1}$ \\ ${ }^{1}$ Akdeniz Üniversitesi Sağllk Bilimleri Fakültesi Gerontoloji Bölümü, Antalya \\ ${ }^{2}$ Aile Çalışma ve Sosyal Hizmetler Bakanlığı Engelli ve Yaşlı Hizmetleri Genel Müdürlüğü, Ankara \\ ${ }^{3}$ Antalya Büyükşehir Belediyesi \\ ${ }^{4}$ Süleyman Demirel Üniversitesi, Eğirdir Sağlık Hizmetleri Meslek Yüksekokulu, Isparta, Türkiye \\ ${ }^{5}$ İstanbul Gelişim Üniversitesi Sağlık Bilimleri Yüksekokulu Gerontoloji Bölümü, İstanbul
}

Amaç: $\mathrm{Bu}$ çalışma covid-19 pandemisi nedeniyle sokağa çıkma yasağı deneyimleyen yaşlı popülasyonun bu kısitlamaya yönelik tepkileri konusunda bir fikir edinmeyi amaçlamaktadır.

Gereç ve Yöntemler: Araştırmanın örneklemini 60+ Tazelenme Üniversitesi öğrencileri arasından tesadüfen seçilen 120 katılımcı oluşturmaktadır. Katılımcılara telefon yolu ile sekiz soruluk k1sa bir anket uygulanmıştır. Verinin tanımlayıcı istatistikleri sunulmuş ve katılımcıların yaşı ile cevapları arasındaki ilişkiyi değerlendirebilmek için korelasyon analizi uygulanmıştır.

Bulgular: Katılımcılar genel olarak, sokağa çıkma yasağ1 karşısında sağduyulu bir tutum sergilemelerine karşın, evde kalmanın virüsün yayılmasını önlemeyeceğini (\%41), virüse bağlı yaşlı ölümlerde azalma yaratmayacağını (\%57) ve bu sürecin yaşlıları 'günah keçisi' haline getirdiğini düşünmektedirler.

Sonuç: Toplumsal yaşama katılımlarını özendirmek için "aktif ol", "dışarı çık", "topluma katıl” dediğimiz yaşlılara bugün "evde kal", diyoruz. Bu yeni durumda, normal koşularda yaşlılar için iyi olan, bugün kendileri için hayati riskler barındırmaktadır. Bu durumda sokağa çıkma yasağı bağlamında yaşlıların sorumluluk üstlenmesi bir "bilinçli izolasyon" olarak kabul edilebilir. Ancak bu bilinçli izolasyon, yaşlıları toplumdan uzaklaştırmanın yeni bir gerekçesi ve aracı olmamalıdır. Evde devam eden kaliteli ve sağlıklı bir yaşam için ihtiyaçlara yönelik önlemler devreye sokulmalidır.

Anahtar kelimeler: Yaşlılık, covid-19, sosyal izolasyon
Aim: This study aims to understand the reaction of the older population who experienced curfew restriction due to the covid-19 pandemic.

Material and Methods: The sample of the study consisted of 120 participants randomly selected among students of $60+$ Tazelenme University. A short questionnaire including eight questions was applied to the participants via telephone. Descriptive statistics of the data were presented and correlation analysis was applied to evaluate the relationship between the age of participants and their responds.

Results: Although participants have a modest attitude towards the curfew, they think that staying at home would not prevent the spread of the virus (41\%), decrease in virus-related older deaths (57\%), and has resulted in the older adults to be perceived as "scapegoats".

Conclusions: To encourage their participation in social life, we conventionally say to older adults "be active", "go out", "joint society" and now we call them to "stay at home". What is good for them under normal conditions, particularly close relation to society, appears to possess vital risks. In this situation, taking responsibility for the older adults in the context of the curfew can be considered as a "conscious isolation". However, this deliberate isolation should not be a new intention and instrument to move the older people away from the society. For a quality and healthy life that continues at home, precautions should be put in place.

Keywords: Aging, covid-19, social isolation. 


\section{GİRIŞ}

Dünyamız bir ekosistem krizi yaşamaktadır. $\mathrm{Bu}$ krizin en önemli nedenleri kirlilik, küresel 1sınma, habitat kayıpları ve buna bağlı kitlesel yok oluşlardır. Kitlesel yok oluş (soy tükenmesi) nispeten kısa bir zaman zarfinda mevcut türlerin büyük bir kısmının ortadan kalkmasıdır. Yaklaşık 4 milyar yılı bulan canlılık tarihi boyunca büyük doğa olaylarına ve iklimsel değişiklilere bağlı olarak en az beş büyük kitlesel yok oluş dönemi yaşanmıştır. Günümüzde ise 6. kitlesel yok oluş dönemi içinden geçmekteyiz (1). Bu yeni kitlesel yok oluş döneminin diğerlerinden farkı ise insan eli ile gerçekleşiyor oluşudur. Diğer bir deyişle, şu anda yaşanan ekosistem krizinin nedeni insanoğlunun kendisidir.

İnsanların temel ihtiyaçlarından olan barınma ve beslenmenin yanında konforlu yaşam tercihi, ihtiyaçlarından fazlasına sahip olma tutkusu, israf, lüks, adaletsiz bölüşüm gibi davranışları norm haline getiren tüketim sistemi dünya üzerinde dramatik bir baskıya neden olmaktadır. Tahrip edilen ekosistemlerin yenilenebilmesi için gerekli zaman verilmediği gibi bask1 her geçen gün artmaktadır (2). Bunun yanında, daha önce hiç bulunmadığımız habitatlara yerleşmekte ve daha önce karşılaşma ve temas etme olasılığımızın oldukça zayıf olduğu hayvanlarla doğrudan veya dolayli temas etmek zorunda kalmaktayı.

Tüm bu olgulara paralel şekilde, 1970'li yıllardan günümüze yeni ortaya çıkan hastalıklar olarak isimlendirilen yaklaşı 30 kadar hastalık tanımlanmıştır. Yeni ortaya çıkan hastalıklara yakın zaman örneklerinden biri, misk kedisi tarafindan insanlara bulaştırılan ve etkeni Coronavirus familyasına ait bir virüs olan (SARS-CoV) akut solunum yolu yetmezliği sendromu (SARS)'dur. Asya'da 2002-2003 kış mevsimi boyunca görülen bu salgın 774 ölümle sonuçlanmıştır (3). Daha sonra yine etmeni bir koronavirüs olan MERS (Orta Doğu solunum sendromu) ilk olarak 2012 yılında Suudi Arabistan'da tespit edilmiş ve virüsün bulaştığı hastalardan 858'i hayatını kaybetmiştir. Ülkemizde MERS sebebiyle 2014 y1lı Ekim ayında Suudi Arabistan geçmişi olan bir kişi hayatını kaybetmiştir.

Güncel koronavirüs (COVID-19) salgınının dünyada ve Türkiye'de büyük bir stres kaynağına dönüştüğü açıktır. Bireyler, kurumlar ve hükümetler bu zor dönemi atlatmak ve tekrar normalleşmek için çeşitli önlemleri devreye sokmaktadırlar. Aşı veya etkin bir tedavi bulununcaya kadar, bu stres sürecinin devam edeceği aşikârdır. Türkiye'de ilk koronavirüs vakasına 11.3.2020 tarihinde rastlanmış ve ilk ölüm 17.3.2020 tarihinde gerçekleşmiştir (4). 1.5.2020 tarihi itibariyle vaka sayıs1 122.392, ölüm sayısı ise 3.258 olarak ilan edilmiştir.

Türkiye'de koronavirüs salgınına karşı alınan önlemlerden biri de yaşlılara sokağa çıkma yasağı getirilmesidir. Yasaktan önce ve sonra, sosyal medyada ve toplumda gözlemlenen eğilimler, koronavirüs salgınının günah keçisi olarak yaşlıların seçildiği izlenimini yaratmıştır. Böylece çevrenin, insan için sadece sokak, ev, pazaryeri, market veya trafik olmadığı, aksine bir yaşam alanı olduğu koronavirüs salgınıyla bir kere daha anlaşılmıştır.

Çevre-birey ilişkisi psikolojik, sosyolojik ve sosyal psikolojik açılardan incelenmektedir. Gerontoloji bu alana oldukça geç iştirak etmiştir. Son yıllarda yaşlı ve çevre arasındaki ilişkilere daha fazla ilgi gösterilmektedir. Ekolojik gerontoloji, yaşlı birey ve çevre arasındaki ilişkileri ele almaktadır $(5,6,7)$. Ancak şimdiye kadar bir virüs salgını nedeniyle sokağa çıkma kısıtlaması deneyimleyen yaşlıların algısını inceleyen bir araştırma yapılmamıştır. $\mathrm{Bu}$ nedenle konu hakkında ampirik bilgi yoktur.

Sosyal izolasyonun yaşlılar üzerindeki etkisi çok boyutlu olarak incelenmesi gereken önemli bir konudur. Yaşlanma ile sosyal izolasyon 
yaygınlığı ve riski artmaktadır. Yaşlılar genellikle daha küçük sosyal ağlara sahiptir ve yalnızlığa daha yatkındır. $\mathrm{Bu}$ kısmen yoksunluk deneyiminden ve yaşl11lı̆ıı bireyselleşmeye ve rollerden arınmaya eğilimi ile ilişkilendirilebilmektedir. Ülkemizin artan yaşlı nüfusu ve yaşlanma deneyimi göz önüne alındığında, yaşlıların sosyal ihtiyaçlarını ve iletişim ağlarını değerlendirmek önemlidir. Yalnızlık hissi, bu bireylerde diğer hastalıkların artmasında önemli bir faktör olabilir (8). Bazı çalışmalar, izolasyon ve yalnızlı̆̆ın sağlık ve mortalite üzerindeki etkisinin, yüksek tansiyon, obezite ve sigara içme gibi risk faktörleri ile aynı büyüklükte olduğunu göstermektedir. Ayrıca, yalnızlık ve yalnızlığın sağlık üzerindeki etkilerinin altında yatan mekanizmalar hakkında bilinenleri de gözden geçirmek gerekmektedir (9). Sosyal izolasyonla birlikte deneyimlenemeyen değer verme ve değer görme hissi aynı zamanda yaşamın tüm dönemlerinde önemli bir ihtiyaçtır. Bu duyguyu, yaşlanma, karar alma sürecindeki aksaklıklar ve pandemi sırasında yaş ayrımcılığı, dağıtıcı adalet ve ekonomi mesajlarıyla karşılaştırarak okumak gerekmektedir (10).

Türkiye'de yaşlıların koronavirüs salgını nedeniyle deneyimledikleri sokağa çıkma yasağına ilk tepkilerini tespit etmek için yapılan telefon anketi, bu bilgi boşluğunu dolduramaz, fakat bu konuda atılan bir adım olarak kabul edilebilir. Tesadüfi örneklem yöntemiyle 60+Tazelenme Üniversitesi öğrencileri üzerinde yapılan bu araştırma, bu popülasyonun sokağa çıkma yasağına yönelik tepkileri konusunda bir fikir edinmeyi hedeflemektedir.

\section{GEREÇ VE YÖNTEMLER}

\section{Teori}

Psikolojide, teori tasarımı ve araştırmalarda "çevrenin" dikkate alınması gerektiğini ilk kez Hellpach (1924) "Psikoloji ve Çevre" başlı̆̆ını taşıyan makalesinde dile getirilmiş ve insanın çevreye bağlı olarak analiz edilmesini önermiştir (11). Üç tür çevre arasında ayırım yapmıştır: Doğa, insan çevresi ve kültürel çevre. Bugün çevre psikolojisinde tartışılan teorik ve metodolojik boyutlar, Hellpach'in araştırma programında da vardı. Teorik boyutta yaşantı ve davranışların koşullarını belirleyen çevre faktörleri dikkate alınmaktadır. Metodolojik boyutta ise insanın çevresi ve çevredeki yaşantı ve davranışları "kompleks bir bağımlılık yapısı" olarak incelenmektedir. Jacob von Uexküll'e (1909) göre canlılar açısından ve böylece insan açısından da fiziksel çevre bir yaşam alanıdır (12). Bu açıdan bakıldığında uygulanan sokağa çıkma yasağının, yaşlıların yaşam alanı ile irtibatını kesen bir önlem olduğu, başka bir açıdan ise çevrenin yaşlı üzerine bir sonucu olarak değerlendirilebilir.

Sosyal bilimsel araştırmalardan teoriye bağl1 açıklamalar talep edilmektedir (13). Koronavirüs salgını ile ilgili teorik açıklama perspektifine stres kavramının yerleştirilmesi, bize makul bir bakış açısı olarak görünmektedir. Winfried Saup'un (1993) aktardığı bilgilerden yola çıkarak, araştırmada uygun görünen Kermit Schooler'in (1982) stres modeli ile çalışacağız (Şekil 1).

Schooler (1982), yaşliların çevrelerine tepkilerini açıklamak için daha önce üzerinde çalışılmış bir stres modelini kullanmaktadır. Lazarus'un bilişsel stres teorisinden hareket etmektedir. Bu teoriyi takiben, birey-çevreetkileşiminin süreç karakterini vurgulamaktadır. Model, yalnızca bireysel davranış ve deneyim etkilerine (stresli veya zorlayıcı) bağlı çevresel koşullarla yüzleşmekle kalmaz, aynı zamanda merkezi etki faktörleri olarak çevresel koşullarla bireysel etkileşimin bilişsel, davranışsal ve duygusal biçimlerini de dikkate alır. Schooler'in yaklaşımında ne kişisel ne de çevresel spesifik özellikler belirtilmiştir. Odak noktası sadece insanlar ve çevre arasındaki etkileşimdir (5). 


\section{Örneklem}

Araştırmanın örneklemi, 60+Tazelenme Üniversitesi öğrencileri arasından tesadüfen seçilen 120 kişidir. Bunların 62'i erkek (\%51) ve 58'i (\%48) kadındır. Katılımcıların 95'i (\%79) evli, 18'i (\%15) dul ve 7'si (\%6) evli değildir. En genci 65 , en yaşlısı 73 yaşındaki katılımcıların yaş ortalaması $68^{\prime} \operatorname{dir}(\mathrm{SD} 2,4)$. 60+Tazelenme Üniversitesi öğrencilerinin eğitim düzeyi bakımından oldukça homojen bir popülasyondur.

\section{Korelasyon Analizi}

Bilimsel bir araştırmanın iki değişkeni arasındaki ilişkiyi analiz etmek sık rastlanılan bir durumdur. Korelasyon nedensellik ile aynı değildir. Korelasyon analizi sadece iki değişkenin ilişkili olup olmadığına ve ne ölçüde ilişkili olduklarına dair bir değerlendirmeye izin verir. Ancak bağlantılarının doğasına dair bir ifadeye izin vermez (14). Nedene ilişkin modellerin hangisinin geçerli olduğuna, iki değişken arasındaki korelasyon değil, ilgili teori altında karar verilir. Korelasyonları yorumlamak için sadece mantık ve makul sonuçlar sağlam bir temel oluşturur (16). Katılımcıların yaşının algıları ile ilişkili olup olmadığını, ilişki varsa ne yönde ve şiddete olduğunu belirlemek için, yaş ve her bir soru değişken olarak ele alınmıştır. Aralıklı, sıralama ve sinıflandırma ölçekli veriler için uygulanan korelasyon analizi yapılmıştır (14).

\section{Etik Kurul Onayı}

Ulusal Sosyal Uygulamalı Gerontoloji Derneği Etik Kurulu 2016.204.14.04.20 etk:-17 sayıl1 araştırma projesi etik uygunluk belgesi alınmıştır.

\section{BULGULAR}

Katılımcılara 8 soru yöneltilmiştir. Görüşmeler yaklaşık 5 dakika sürmüştür. Katılımcılardan, cevap seçeneklerinden birini seçmeleri istenmiştir. Tablo I'de cevapların dağılımları görülmektedir.

Katılımcıların \%56'sı sokağa çıkma yasağını doğru bir karar olarak değerlendirmiştir. Yaklaşık \%31'i ise bu kararı doğru bulmadığını belirtmiştir (Soru 1).

Sokağa çıkma yasağının yaşlı insanların toplumda algılanışına olumsuz etkileri olacağına yaklaşık \%33'ü inanırken, yaklaşık \%42'si yaşlıların toplumda algılanışına olumlu etki yapacağını düşünmektedir. Ancak katılımcıların dörtte biri (\%25), bu konuda kararsız bir tutum sergilemiştir (Soru 2).

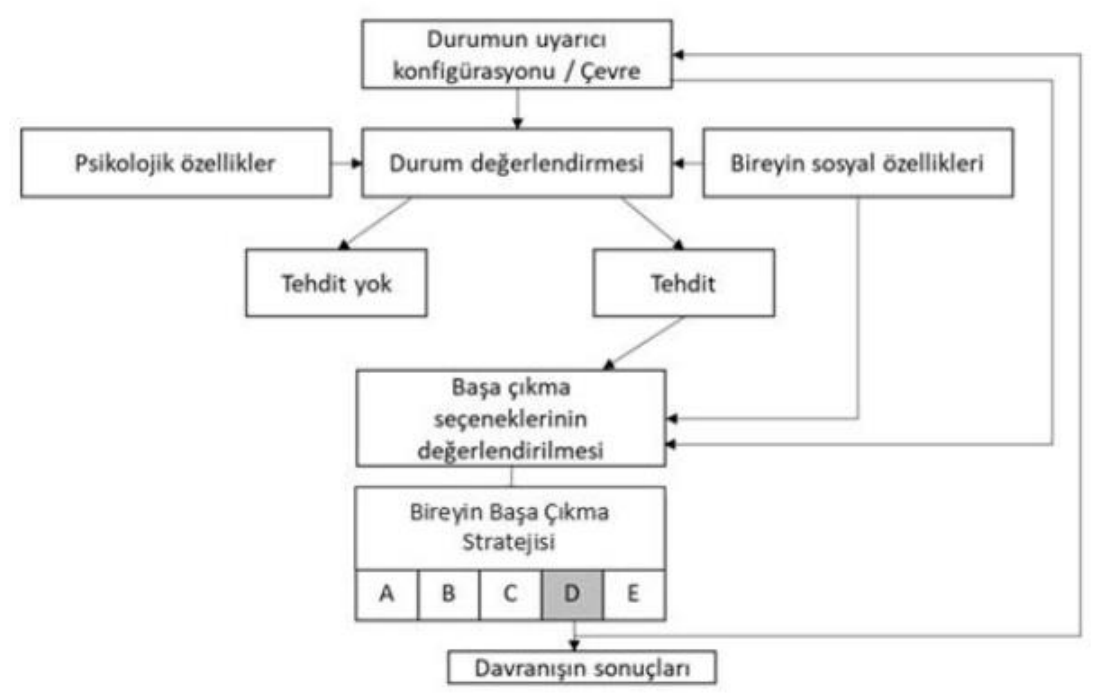

Şekil 1. Schooler'in stres teorisine dayanan modeli (Saup 1993) 
Tablo I. Telefon anketi soruları ve cevap dağılımları (\%)

\begin{tabular}{|c|c|c|c|c|c|}
\hline \multicolumn{2}{|c|}{$\begin{array}{l}\text { Sorı 1: } \\
\text { Yaşlılara getirilen sokağa çıkma } \\
\text { yasağın nasıl } \\
\text { değerlendiriyorsumuz? }\end{array}$} & \multicolumn{2}{|c|}{$\begin{array}{l}\text { Soru } 2 \text { : } \\
\text { Bu yasak yaşlılarnn toplumdaki } \\
\text { alglanışım olumsuz mu, olumlu } \\
\text { mu etkiler, yoksa etkilemez mi? }\end{array}$} & \multicolumn{2}{|c|}{$\begin{array}{l}\text { Soru 3: } \\
\text { Bu yasak adil mi, yoksa adil } \\
\text { değil mi? }\end{array}$} \\
\hline Çok doğru buluyorum & 28,3 & Çok olumlu etki & 15,8 & Çok adil & 37,5 \\
\hline Doğru buluyorum & 28,3 & Olumlu etki & 26,7 & Adil & 14,2 \\
\hline Ne biri ne diğeri & 12,5 & Ne biri ne diğeri & 25,0 & Ne biri ne diğeri & 8,3 \\
\hline Doğru bulmuyorum & 16,7 & Olumsuz etki & 25,0 & Adil değil & 30,0 \\
\hline Hiç doğru bulmuyorum & 14,2 & Çok olumsuz etki & 7,5 & Hiç adil değil & 10,0 \\
\hline \multicolumn{2}{|c|}{$\begin{array}{l}\text { Soru 4: } \\
\text { Bu yasak korona virüsünden ölen } \\
\text { yaşh sayısını azaltır mı? }\end{array}$} & \multicolumn{2}{|c|}{$\begin{array}{l}\text { Soru 5: } \\
\text { Yasağın herkese uygulanmasina ne } \\
\text { dersiniz? }\end{array}$} & \multicolumn{2}{|c|}{$\begin{array}{l}\text { Soru 6: } \\
\text { Bu yasak virïsïn yayılmasım } \\
\text { frenler mi? }\end{array}$} \\
\hline Hiç azaltmaz & 34,2 & En doğrusu budur & 12,5 & Kesinlikle frenler & 14,2 \\
\hline Azaltmaz & 22,5 & Doğrusu budur & 17,5 & Frenler & 26,7 \\
\hline Ne biri ne diğeri & 15,8 & Ne biri ne diğeri & 9,2 & Ne biri ne diğeri & 22,5 \\
\hline Azaltır & 8,3 & Doğru olmaz & 40,8 & Frenlenemez & 27,5 \\
\hline Çok azaltır & 19,2 & Hiç doğru olmaz & 20,0 & Hiç frenlemez & 9,2 \\
\hline \multicolumn{2}{|c|}{$\begin{array}{l}\text { Soru 7: } \\
\text { Yaşlllar "günah keçisi" mi oldu? }\end{array}$} & \multicolumn{2}{|c|}{$\begin{array}{l}\text { Soru 8: } \\
\text { Sokağa çıkna yasağından dolayı } \\
\text { kendimi bağımlı hissediyorum. }\end{array}$} & & \\
\hline Kesinlikle doğru & 29,2 & Hiç doğru değil & 13,3 & & \\
\hline Doğru & 33,3 & Doğru değil & 26,7 & & \\
\hline Ne biri ne diğeri & 10,0 & Ne biri ne diğeri & 24,2 & & \\
\hline Doğru değil & 17,5 & Doğru & 18,3 & & \\
\hline Hiç doğru değil & 10,0 & Çok doğru & 17,5 & & \\
\hline
\end{tabular}

Tablo II. Katılımcıların yaşı ile cevapları arasında gözlenen korelasyon

\begin{tabular}{|c|c|c|c|}
\hline Soru & Yaş & Yaş (Karşıt) & Yaş (Taraftar) \\
\hline S1: Yasağ1 değerlendirme & $-38^{\text {*2* }}$ & $-34^{\text {*2* }}$ & $-41^{* *}$ \\
\hline S2: Yaşlı alg1sına etkisi & $37^{* *}$ & $31^{2 *} \cdot$ & $48^{* *}$ \\
\hline S3: Yasak adil/adil değil & $-34^{* *}$ & $-23^{* *} \cdot$ & $-43^{* *}$ \\
\hline S4: Ölümü azaltır/azaltmaz & 10 & 12 & 06 \\
\hline S5: Herkese uygulanmalı & -02 & -11 & 03 \\
\hline S6: Virüsün yayilmasina etkisi & -01 & -06 & 13 \\
\hline S7: Yaşlılar "günah keçisi" & -002 & -04 & -02 \\
\hline S8: Bağımlılık duygusu & $55^{\text {*** }}$ & $58^{* * *}$ & $47^{* *}$ \\
\hline $\begin{array}{l}\text { Açlklama: Değerler, Spearman-Rho korelas } \\
\text { "0" yazılmamıştr. }{ }^{* *} \text { işareti, istatistiksel a } \\
\text { yaşına göre hesaplanmıştr. İkinci sütunda g } \\
\text { ve "taraftarn" olarak sinflandırnlan denekler }\end{array}$ & saylant & $\begin{array}{l}\text { kumayl kolaylaşttrm } \\
0,01) \text { ifade etmektedi } \\
\text { düncü sütunlarda sol } \\
\text { lasyon değerleri veril }\end{array}$ & $\begin{array}{l}\text { için değerlerin önündeki } \\
\text { Korelasyonlar deneklerin } \\
\text { sa çıma yasağı "karş̧tt" } \\
\text { știr. }\end{array}$ \\
\hline
\end{tabular}

Katılımcıların \%40’1 sokağa çıkma yasağının adil olmadığını, buna karşın \%52'si adil olduğunu kabul etmektedir (Soru 3).

Sokağa çıkma yasağının yaşlılarda koronavirüs bağlı ölümlerde azalma yaratmayacağına yaklaşık \%57'si, yaşlı ölümlerinde azalma yaratacağına ise \%27'si inanmaktadır (Soru 4).
Katılımcıların \%30’u sokağa çıkma yasağının herkese uygulanması gerektiğine inanmaktadır. Yaklaşık \%61'i ise herkese uygulanmasını doğru bulmamaktadır (Soru 5).

Katılımcıların\%41'i sokağa çıkma yasağı ile virüsün yayılmasının önlenemeyeceğine, buna karşın \%37'si önleneceğine inanmaktadır (Soru 6). 
Katılımcıların \%62'si sokağa çıkma yasağının, yaşlıları "günah keçisi" haline getirdiğini düşünmektedir. Yaklaş1k \%28'i bu görüşü reddetmektedir (Soru 7).

Sokağa çıkma yasağı nedeniyle kendisini bağımlı hissetmeyen katılımcıların oran1 $\% 40$ iken, yaklaşık \%36'sı kendisini bağımlı hissettiğini söylemektedir (Soru 8).

\section{TARTIŞMA}

Koronavirüs salgını yaşlılar üzerinde stres ve baskı yaratan bir süreç olarak kabul edilirse, aktarılan ampirik bilgiler ve bulgular, çevresel koşulların yaşlilar üzerindeki etkileri olarak değerlendirilebilir. Scholer'in stres teorisine dayanan modelinde çevresel koşulların yaşlılar üzerindeki etkilerinin teorik açıdan değerlendirilmesi aşağıdaki şekilde karakterize edilebilir (5).

Yaşlının çevre ile başa çıkma sürecinde ilk bağlantı çevresel koşullarla yüzleşmektir. Uyaran konfigürasyonunun özellikleri, mevcut çevresel özelliklerden, çevre koşullarındaki bir değişiklikten veya ortamdaki bir değişikliğin ilişkili olduğu kişinin mekânsal hareketliliğinden oluşabilir. Burada bu "yüzleşme" koronavirüs salgını nedeniyle sokağa çıkma yasağının getirilmesi ile gerçekleşmiştir. Bireyin karşı karşıya kaldığı (yeni) çevre koşulları, kişi tarafindan bireysel tarzla algılanmış ve değerlendirilmiştir. Değerlendirme süreci yalnızca yeni koşulların yarattığı uyaran konfigürasyonunun özelliklerine bağlı değildir. Bireyin (bu araştırmada incelenmemiş olan) psikolojik ve sosyal özelliklerinden de etkilenmektedir. Birey çevresel koşulları "tehdit" veya "tehdit edici değil" şeklinde iki türlü değerlendirmiştir. $\mathrm{Bu}$ değerlendirme süreci, sadece yeni çevresel koşulların uyaran konfigürasyonunu algilamak ve değerlendirmek değildir. Aynı zamanda birey, kişisel yetkinliğini ve tehdit edici çevresel koşullarla başa çıkma kaynaklarını da değerlendirmektedir. $\quad \mathrm{Bu}, \quad$ durum değerlendirmesini, başa çıkma değerlendirmesi takip etmektedir. Ayrıca bireyin başa çıkma olasılıklarını değerlendirmesi, kişinin psikolojik ve sosyal özellikleri yanında uyaran konfigürasyonunun özelliklerine de bağlidır. Söz konusu yasağın yürürlüğe koyulmasının ardından birey bu stres faktörüne cevaben uyum sağlamak veya karşı çıkmak tutumlarıyla açıklanabilen başa çıkma mekanizmaları geliştirmiştir. Tablo I ve Tablo II'de görüldüğü şekliyle sokağa çıkma yasağının katılımcıların $\% 56$ 's1 tarafından doğru ve \%52'si tarafından adil olduğunu düşünmeleri çevresel stresörlere psikolojik ve sosyal altyapıları ile uyum sağlamaya çalıştıkları anlamına gelebilir.

Koronavirüs salgınının bir tehdit olarak görüldüğü kabul edilebilir. Sokağa çıkma yasağının bu tehdidi daha da güçlendirip güçlendirmediğini bilmiyoruz. Böyle bir etkinin yaşlıya ne ölçüde faydası veya zarı olur, bu konuda bir fikir beyan edemeyiz. Ancak birey, tehdit altında olduğunu düşündüğü çevresel koşullara yanıt olarak, durumla başa çıkmak için bilişsel, davranışçı veya duygusal çabalarını güncelleyebilir. Örneğin bunlar, tehdit edici çevresel koşulları değiştirmeyi amaçlayabilir. Bu süreç kişilerin stresi algılama şekilleri ve kişisel seçimleriyle yakından ilişkilidir. Schooler'in Şekil 1'de söz edilen teorisinde $\mathrm{A}$ seçeneğinden $\mathrm{E}$ seçeneğine doğru değişebilen davranış motifleri bu durumla ilişkilidir. Bulgulara bakıldığında katılımcıların \%42'si halk sağlığı için alınan ileri yaşlı bireylere yönelik sokağa çıkma yasağının toplumdaki yaşlı algısını olumlu etkileyebileceğini düşünürken buna karşı bir görüşle \%62'lik bir orana sahip olan ciddi bir çoğunluk bu kararın yaşlıları günah keçisi ilan ettiğini düşünmektedir. Bu görüş farklılıkları yaşlıların pandemi ve sokağa çıkamamanın yarattığ strese cevap verme süreçlerindeki farkl1lıklardan ileri gelmektedir. 
Çevresel değişikliklerle yüzleşmenin ve incelenmesinin kişisel bir sonucu olarak, Schooler (1982), yaşlı insanların öznel ruh halindeki değişimi incelemektedir (5). Ancak çoğu yaşlının sokağa çıkma yasağını gerekli bulması yanında önemli bir kısmının da gereksiz bulması bu önlemin etkililiği konusunda şüpheleri olduğuna işaret etmektedir (Tablo I). Kat1lımciların \%57'si alınan kararların yaşlı ölümlerini azaltmayacağına, \%41'i sokağa çıkma yasaklarının ölüm oranlarını düşürmeyeceğine inanmaktadır. $\mathrm{Bu}$ durum, katılımcıların öznel ruh hallerinde ikincil bir stres kaynağı olarak yorumlanabilmektedir. Schooler'in strese yanıt süreci dahilinde pandeminin birincil olarak yarattığ1 tehditle bağlantılı olan izolasyon ve yasaklardan kaynaklı ikincil değişimin yaşlılar nezdinde toplumdaki konumları, bağımsızlıkları ve sağ kalımları adına kişisel olarak yorumlandıklarını söylemek mümkündür. Katılımcıların \%40'ının yasak sürecinde kendilerini bağımlı hissetmemeleri bu sürece dair uyum çabası olarak okunabilmekle birlikte yasağın herkese uygulanmamasını destekleyen çoğunluğun (\%61) mevcudiyeti, yaşlıların genel olarak sokağa çıkma yasağını "tolere edilebilir düzeyde bir stres kaynağı” olarak görmeleri anlamina gelmektedir.

\section{SONUÇ}

Sokağa çıkma yasağı gençlik ideolojisine ne denli bağımlı olduğumuzu göstermiştir. Ancak bu kez geçmişin unutulması ve yaşlı1ığın nurlandırılması şeklinde devam etmemiştir. Sorunlu güncel yaşlılığın yerine dünkü sözde talihli, bahtiyar yaşlıların dünyası konulmamıştır. Büyük aile, genç ve yaşlı kuşakların mükemmel bir uyum içinde birlikte yaşadıkları, yaşlıların korunup kollandıkları, anlam dolu bir yaşam sürdükleri, ferahlatıcı aile modele dönüştürülmemiştir. Aksine onlar için iyi olduğu kabul edilerek, fikirleri sorulmadan evlerine hapsedilmişleridir. Bir insanın başına gelebilecek ne kadar kötülük varsa, yaşl1lıkla örtüştürülürken, bu kez, insanc1l özellikleri kaybolan toplumda insana saygı boşluğu, yaşlıya saygı ile doldurulmaya çalışılmamıştır (17).

Yaşlıları özellikle de yalnız yaşayan yaşlıları zor bir süreç beklemektedir. Yalnızlık, çoğunlukla diğer insanlardan ayrılma ve izole olma hissini tanımlar. Sokağa çıkma yasağı öncelikle bu yaşlılar açısından olumsuz sonuçlar doğurabilir. Ancak yaşlının yakın sosyal çevresi, bu sürecin daha kolay atlatılmasına katkı sağlayabilir.

Koronavirüs salgınından beri, yaşlıları evde tutma konusunda zorluk çekiyor gibi görünüyoruz. Bir ilimizde 65 ve üzeri yaştaki kişilerin ücretsiz kamu taşıtlarından yararlanması, geçici süre için kaldırıldı. Sokağa çıkma yasağından önce gelen bu önlem, yaşlıların birçoğunu eve bağladı. Sokağa çıkma yasağı, yaşlıların "eve hapsolmuş" duygusuna kapilmalarını engelleyecek yeni önlemlere ihtiyaç yaratmıştır. Örneğin televizyonda yaşlılara özel programlar sunulabilir veya bu dönemi bir "nostaljik süreç" olarak atlatmalarına katk1 sağlanabilir. Akrabaları, çocukları, torunları ve komşuları, yaşlılara bu zor süreçte yardımcı olabilirler.

Yıllardır yaşlılara "aktif ol", "dışarı çık", "topluma katıl" dedik. Bu kez, "evde kal", diyoruz. Bu çelişki, durumların düşünceleri, talepleri, davranışları, hareketleri, belirlediğini gösteriyor. Yeni bir durum ile karşı karşıyayız. Normal şartlarda yaşlılar için iyi olan, bugünkü koşullarda onlar açısından hayati tehlike taşıyor ve çevresindeki insanları da ilgilendiriyor. $\mathrm{Bu}$ bağlamda sokağa çıkma yasağı, yaşlıların sorumluluk üstlenmesi bir "bilinçli izolasyon" olarak kabul edilebilir. Ancak bu bilinçli izolasyon, yaşlıları toplumdan uzaklaştırmanın yeni bir gerekçesi ve aracı olmamalıdır.

Sokağa çıkma yasağı yaşlılarda depresyona yol açar $\mathrm{m}$ ? $\mathrm{Bu}$ soruya da sıkça rastlıyoruz. Koronavirüsten korunmak için evden çıkmaması, yaşlıdaki mevcut depresyonu 
arttırabilir. Depresyon hastası yaşl1ların dezavantajı, günlük yaşamın organizasyonunda yaşadıkları sıkıntılardır. Depresyon, ağır bir ruhsal problemdir $(18,19,20)$. Depresyonun altında sokağa çıkma yasağından daha fazlası yer almaktadır. Bir insan birkaç hafta veya ay evden dışarı çıkmazsa, sırf "yaşlı" olduğu için depresyon hastası olmaz.

Sokağa çıkma yasağı yaşlılarda depresyon tehlikesinden ziyade, evde düşme kazası tehlikesi yaratacaktır. Özellikle 75 yaşından itibaren düşme kazası tehlikesi artmaktadır. Her yıl yüzbinlerce yaşlının düşme kazası nedeniyle sakat kalarak bakıma muhtaç olduğunu biliyoruz (21). Düşme kazaların önemli bir kısmı evde meydana geliyor. Ancak sokağa çıkma yasağı yaşlıları evlerine hapsetmiştir. $\mathrm{Bu}$ yüzden düşme kazaların sebebi değil, ama düşme kazalarının evde meydana gelme olasılığını arttıran bir sebeptir. Sokağa çıkma yasağı, bu açıdan yaşlılıkta ikamet ve bunun koşulları üzerine düşünmek için bir firsat olarak da kabul edilebilir ve yaşlanan toplumumuzda yeni ikamet biçimlerinin gerekli ve en azından sokağa çıkma yasağı kadar iyi bir önlem olarak kabul edilebilir (22).

İnsan stresli durumlardan sonra tamamen olmasa da iyileşebilir. Her zaman az da olsa bir iyileşme açı̆̆ı kalmaktadır ve yaşlanmanın hızını arttırmaktadır. Ancak bunun deneysel kanıtlarının henüz ortaya konulmadığını belirtmek gerekir (23). Bu açıdan bakıldığında, sokağa çıkma yasağının, yaşlının yakın sosyal çevresinde yarattığ 1 stresin de göz önüne alınması gerekir. Muhtemelen güncel bask1 ve stres atlatıldıktan sonra da, bu kişilerde az-çok kalıcı etkileri olacaktır.

Korona virüsü özellikle yaşlilardan bireysel inisiyatif ve sorumluluk bekliyor. Ama bu sorumluluğu üstlenemeyecek durumda olan yaşlilar da vardır. Bu bağlamda ilk akla gelen Alzheimer hastalarıdır (23). Ancak şimdiye kadar bu yaşlılar ve aileleri için hiçbir öneri getirilmemiş ve hiçbir önlem alınmamıştır.
Yaşl1lık insanı kendiliğinden akıllı veya bilge yapmaz. Hepimiz tarafindan karşılanması gereken büyük bir tehlike var ve bu tehlikeyi ancak yükleneceğimiz bireysel sorumluluk ve önlemlerle aşabiliriz. Herkes gibi yaşlılar da bu sorumluluktan kaçmamalıdır. Hem kendilerini hem torunlarını düşünmelidirler.

Covid-19 salgınının sıcak gündemimiz olması nedeniyle şu anda sadece hastalıktan korunma ve tedavi konularına odaklanmaktayız. Ancak, bu dar bakış açısı gelecekte bizi bekleyen felaketlerden korumaya yetmeyecektir. Bu ve buna benzer yeni hastalıkların görülmesi ne ilk ne de son olacaktır. İnsan türü olarak diğer türlerle beraber yaşadığımızın bilincinde olmak zorundayız. Dünyayı fütursuzca kullanmaya ve tahrip etmeye devam ettiğimiz, doğadan sağladığımız kaynakları daha adil ve eşit bölüştürmenin bir yolunu bulamadığımız ve ihtiyacımızdan fazlasını (konfor, lüks tüketim çılgınlığ $1 \mathrm{vb}$.) istediğimiz sürece çocuklarımıza bırakacağımız güvenli bir dünya olmayacaktır.

\section{Çıkar Çatışması ve Fonlama}

Çalışma için finansal destek alınmamıştır. Yazarlar çıkar çatışması olmadığını belirtir.

\section{Etik Kurul Onayı}

Ulusal Sosyal Uygulamalı Gerontoloji Derneği Etik Kurulu 2016.204.14.04.20 etk:-17 sayıl1 araştırma projesi etik uygunluk belgesi alınmıştır.

\section{KAYNAKLAR}

1. Freeman S, Herron JC. Evrimsel Analiz, Çeviri Editörleri: Çıplak B, Başıbüyük HH, Karaytuğ S, Gündüz İ. 4. Baskı, Ankara, Palme Yayıncılık, 2009.

2. Pullin AS. Conservation Biology Fourth Printing, Cambridge, Cambridge University Press, 2007.

3. Leveque C, Mounolou JC. Biyoçeşitlilik: Biyolojik Devinimler ve Koruma, Çeviri Editörleri: Bașıüyü̈k HH, Yılmaz A, Kılınç S. 2. Baskı, Ankara, Palme Yayıncılık, 2013.

4. T.C. Sağlı Bakanlığı COVID-19 (SARS-Cov-2 Enfeksiyonu)RehberiBilim Kurulu Çalışması: Ankara, 29 Haziran2020, 11-13. [https://covid19bilgi.saglik.gov.tr/depo/rehberler/covid-19rehberi/COVID- 
19_REHBERI_GENEL_BILGILER_EPIDEMIYOLOJI_V E_TANI.pdf] Erişim tarihi: 01. 08. 2020.

5. Saup W. Alter und Umwelt. Eine Einführung in die Ökologische Gerontologie. Stuttgart, Kohlhammer Verlag, 1993, 45-47.

6. Wahl HW, Mollenkopf H, Oswald F. Alte Menschen in ihrer Umwelt. Opladen, Westdeutscher Verlag, 1999.

7. Kruse A. Ältere Menschen im "öffentlichen Raum": Perspektiven einer altersfreundlichen Kultur. Editörler WahlHW,Mollenkopf H.Alternsforschung am Beginn des 21. Jahrhunderts. Alterns- und Lebenslaufkonzeptionen im deutschsprachigen Raum. Berlin, Akademische Verlagsgesellschaft, 2007, 345-379.

8. Seyfzadeh A, Haghighatian M, Mohajerani A. Social Isolation in the Elderly: The Neglected Issue. Iran J Public Health. 2019;48(2):365-366.

9. Singer C Health Effects of Social Isolation and Loneliness Journal of Aging Life Care https://www.aginglifecarejournal.org/health-effects-ofsocial-isolation-and-loneliness/

10. Flett GL, Heisel MJ. Aging and Feeling Valued Versus Expendable During the COVID-19 Pandemic and Beyond: a Review and Commentary of Why Mattering Is Fundamental to the Health and Well-Being of Older Adults [published online ahead of print, 2020 Jun 15]. Int J Ment Health Addict. 2020;1-27. doi:10.1007/s11469-020-00339-

11. Hellpach W. Psychologie der Umwelt. Editör Abderhalden E. Handbuch der biologischen Arbeitsmethoden.Wien, Urban \& Schwarzenberg, 1924, (s. VI, Teil C, Heft 3).

12. Fietkau HJ. Umweltpsychologie. Editörler Asanger R, Wenninger G. Handwörterbuch Psychologie. Weinheim, Beltz, Psychologie Verlags Union, 1999, 808-811.

13. Atteslander P. Methoden der empirischen Sozialforschung, 13. Aufl. Berlin, Erich Schmidt Verlag,2010.

14. Tufan İ. Gerontologdan Meraklisina İstatistik Müsveddeleri. Ankara, İstanbul, Nobel Akademik Yayıncilık, 2015.

15. Schendera CFG. Datenmanagement mit SPSS: Kontrollierter und beschleunigter Umgang mit Datensätzen, Texten und Werten Berlin, Springer, 2005: 15

16. Borscheid P. Der alte Mensch in der Vergangenheit. Editörler BaltesP., Mittelstraß J. Zukunft des Alterns und gesellschaftliche Entwicklung, Forschungsbericht5Berlin, New York Walter de Gruyter, 1992, 34-61.
17. Wolter-Henseler DK. Depressionen im Alter. Erscheinungsformen und Behandlung. Editör Breloer G. Sinnfragen im Alter. Münster, New York, Waxman,2000.

18. Wolfersdorf $M$, Schüler $M$. Depression im Alter. Diagnostik, Threapie, Angehörigenarbeit, Fürsorge, Gerontopsychiatrische Depressionstationen. Stuttgart, Kohlhammer, 2005.

19. Niklewski G. Depression. Editörler OswaldWD, Lehr U, SieberC, Kornhuber J., Gerontologie: Medizinische, psychologische und sozialwissenschaftliche Grundbegriffe. Stuttgart, Kohlhammer, 2006, 48-55.

20. Tufan İ. Birinci Türkiye Yaşlılık Raporu. Antalya: GeroYay, 2007.

21. Mollenkopf H, Oswald F, Wahl HW. Wohnen und Umwelt. Editörler OswaldWD, Lehr U, Sieber C, Kornhuber J. Gerontologie: Medizinische, psychologiesche und sozialwissenschaftliche Grundbegriffe, 3.Aufl. Stuttgart, Kohhammer, 2006, 398-402.

22. Böger J, Kanowski S.Gerontologie und Geriatrie für Krankenpflegeberufe, 3.Aufl. Stuttgart, Thieme, 1995.

23. Tufan İ. Bakıma Muhtaç - Türkiye'de Alzheimer Hastası Yaşılıarın Bakımı. İstanbul, Koç Üniversitesi Yayınları, 2016.

24. Ejiri M, Kawai H, Fujiwara Y, et al. Social participation reduces isolation among Japanese older people in urban area: A 3-year longitudinal study. PLoS One. 2019;14(9):e0222887. Published 2019 Sep 20. doi:10.1371/journal.pone. 0222887

25. Novotney, A. (2019). The risks of social isolation. American Psychological Association. 50(5), 32.

26. WHO (2020) Coronavirus disease 2019 (COVID-19) Situation Report - 89. https://www.who.int/docs/defaultsource/coronaviruse/situation-reports/20200418-sitrep-89covid-19.pdf?sfvrsn=3643dd38_2 Erișim Tarihi: 01.08 .2020

27. Webb L. COVID-19 lockdown: A perfect storm for older people's mental health [published online ahead of print, 2020 Apr 30]. J Psychiatr Ment Health Nurs. 2020;10.1111/jpm.12644. doi:10.1111/jpm.12644 Erişim Tarihi: 01.08 .2020 